\title{
Characterization of Microstructure and Mechanical Properties of TiNbZr Alloy during Heat Treatment
}

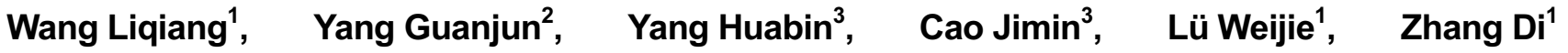 \\ ${ }^{1}$ State Key Laboratory of Metal Matrix Composites, Shanghai Jiaotong University, Shanghai 200240, China; ${ }^{2}$ Northwest Institute for Non- \\ ferrous Metal Research, Xi'an 710016, China; ${ }^{3}$ Xi'an SMA Material Co., Ltd, Xi'an 710016, China
}

\begin{abstract}
TiNbZr alloy was prepared by vacuum consumable arc melting furnace. The effects of solution and aging heat treatment on the microstructure and mechanical properties of this alloy were studied. The results show that ultimate tensile strength over 1000 MPa can be obtained when the alloy is solutioned for $1 \mathrm{~h}$ and then aged at 300 and $350^{\circ} \mathrm{C}$. $\alpha$ phase precipitation appears under the condition of the treatment of solution for $1 \mathrm{~h}$, followed by aging at $400{ }^{\circ} \mathrm{C}$ and $450{ }^{\circ} \mathrm{C}$. The aging time plays an important part in $\alpha$ phase precipitation. The ultimate tensile strength increases to $850 \mathrm{MPa}$ and the elongation keeps around $11 \%$ when the alloy is aged at $400{ }^{\circ} \mathrm{C}$ for $9 \mathrm{~h}$.
\end{abstract}

Key words: $\beta$ titanium alloys; heat treatment; microstructure; mechanical properties

\begin{abstract}
$\beta$ titanium alloys possess excellent properties such as better biocompatibility, higher strength and better plasticity etc. Comparing with $\alpha$ and $\alpha+\beta$ titanium alloys, $\beta$ titanium alloys are now widely used as biomaterials due to their low young's modulus, good processing properties of cold deformation and welding. It has been reported that $\beta$ titanium alloys, consisting of $\mathrm{Nb}, \mathrm{Ta}, \mathrm{Zr}$, Mo and $\mathrm{Sn}$ show good biocompatibility and low toxicity to human being ${ }^{[1]}$. This kinds of alloys such as Ti-29Nb-13Ta-4.6Zr ${ }^{[2]}$, Ti-34Nb-9Zr-8Ta ${ }^{[3]}, \quad$ Ti-16Nb-5Sn ${ }^{[4]}$ and $\mathrm{Ti}-22 \mathrm{Nb}-\mathrm{Ta}^{[5]}$ are developed and used widely. New types of $\beta$ titanium alloys including the elements of $\mathrm{Nb}, \mathrm{Zr}, \mathrm{Pd}$ and Ta are being studied as biomedical titanium alloys ${ }^{[6,7]}$. Takashi Saito's group has developed a new kind of titanium alloys ${ }^{[8]}$. In these cold-worked alloys, there appeared dislocation-free plastic deformation mechanism, which contributed to the plastic deformation of the alloys. Recently, the $\beta$-titanium alloys such as Ti-Nb, Ti-Ta and Ti-Zr showing high strength and low elastic modulus have been developed quickly ${ }^{[9-11]}$.

In this paper, we discuss the effect of heat treatment on the microstructure and mechanical properties of TiNbZr alloy. This alloy contains non-cytotoxic elements. It is promising as biomedical implants due to its low young's modulus, excellent workability and aging effect. The aim of this work is to inves-
\end{abstract}

tigate the characterization of phase transformation, the microstructure and the mechanical properties of $\mathrm{TiNbZr}$ alloy treated by solid solution and aging.

\section{Experimental}

TiNbZr alloy was melted twice homogeneously in a consumable vacuum arc remelting furnace to ensure compositional homogeneity. The bar of $\Phi 7 \mathrm{~mm}$ was obtained through the processes of forging and hot rolling. The rolled bar was treated by solid solution at $780{ }^{\circ} \mathrm{C}$ for $1 \mathrm{~h}$. Then the specimen was aged at between $300{ }^{\circ} \mathrm{C}$ and $500{ }^{\circ} \mathrm{C}$ for 2 to $10 \mathrm{~h}$. All specimens were cooled in air. Microstructures were observed by optical microscopy (OM) and scanning electron microscopy (SEM). Samples for optical microscopy (OM) were prepared using conventional techniques of grinding and mechanical polishing. The samples of SEM were etched more deeply than those of OM. The composition of etched solution was hydrofluoric acid, nitric acid and water in proportion of 1:3:6(volume fraction). The phase analysis was carried out by X-ray diffraction (XRD) and tensile test was conducted on Instron1195 tensile testing machine.

\section{Results and Discussions}




\subsection{Microstructure and mechanical properties of the alloy treated by solid solution}

Fig. 1 shows the OM micrograph of TiNbZr treated by solid solution. Typical equiaxial $\beta$ grains appeared when the alloy was treated by solution at $780{ }^{\circ} \mathrm{C}$ for $1 \mathrm{~h}$. As the X-ray diffractiorshown in Fig.2, only reflections of $\beta$ peaks were observed. Kaufman reported ${ }^{[12]}$ that for Ti-Nb alloy $M$ s(start temperature of martensite transformation) decreased with the increase of the content of $\mathrm{Nb}$. Owing to a large amount of $\beta$-stabilizing $\mathrm{Nb}$ element, $M \mathrm{~s}$ decreased below to room temperature. Therefore, no $\alpha^{\prime \prime}$ martensite transformation from $\beta$ occurred when the sample was cooled to room temperature during solid solution. Table 1 shows the mechanical properties of the alloy after solid solution.

\subsection{Microstructure and mechanical properties of the alloy aged at different temperatures}

Fig. 3 shows the microstructure of the alloy treated by solution at $780^{\circ} \mathrm{C}$, followed by aging at different temperatures $\left(300-500^{\circ} \mathrm{C}\right)$ for $4 \mathrm{~h}$. When the alloy was aged at $300^{\circ} \mathrm{C}$ and $350^{\circ} \mathrm{C}$ for $4 \mathrm{~h}$, homogeneous equiaxed gains without any second phase precipitation appeared, as shown in Fig.3a, b. When the aging temperature was $400{ }^{\circ} \mathrm{C}$, little and needle-like phase precipitated densely along gain boundaries and dispersedly inside gains, shown in Fig.3c. Because of low free energy for $\alpha$ phase precipitation along gain boundaries, it was observed easily. Much more net-shaped phase grew up and were interlaced inside gains equably, when the alloy was aged at $450{ }^{\circ} \mathrm{C}$. Fig. $3 \mathrm{~d}$ was the SEM image of the alloy aged at $450{ }^{\circ} \mathrm{C}$. There was no $\alpha$ phase precipitation under the condition of $500{ }^{\circ} \mathrm{C}$ and $4 \mathrm{~h}$ (Fig.3e). Owing to insufficient transforming driving force

Table 1 Mechanical properties after solid solution

\begin{tabular}{ccccc}
\hline Solution condition & UTS/MPa & YS/MPa & EL/\% & RA/\% \\
\hline $780^{\circ} \mathrm{C}, 1.0 \mathrm{~h}, \mathrm{AC}$ & 657 & 395 & 20 & 55.8 \\
\hline
\end{tabular}

from $\beta$ to $\alpha$ phase at $500{ }^{\circ} \mathrm{C}$, no $\alpha$ phase was distinguished under this condition. Fig. 4 shows XRD of the specimen after solution and aging heat treatment. The reflections of $\alpha$ peaks were investigated when the aging temperature was 400 ${ }^{\circ} \mathrm{C}$ (Fig.4a). No any reflections of $\alpha$ peaks were observed when the temperature reached to $500{ }^{\circ} \mathrm{C}$ (Fig. 4 b).

Fig. 5 shows mechanical properties of the specimens after solution and aging heat treatments. Compared with the solution-treated sample, the strength and plasticity of the alloy aged

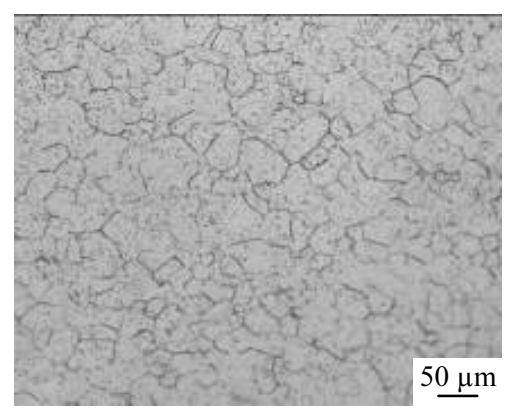

Fig.1 OM micrograph of the specimen after solid solution

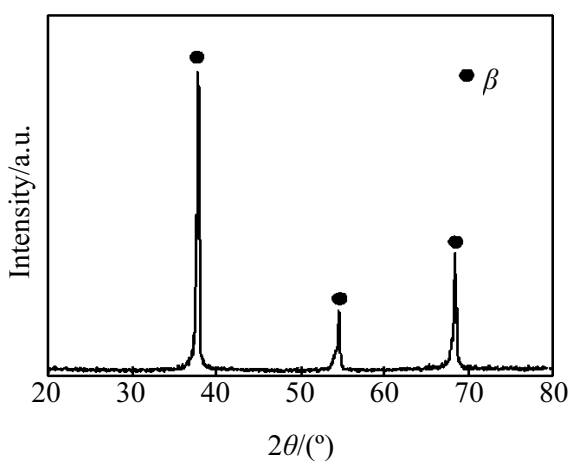

Fig.2 XRD pattern of the specimen after solid solution

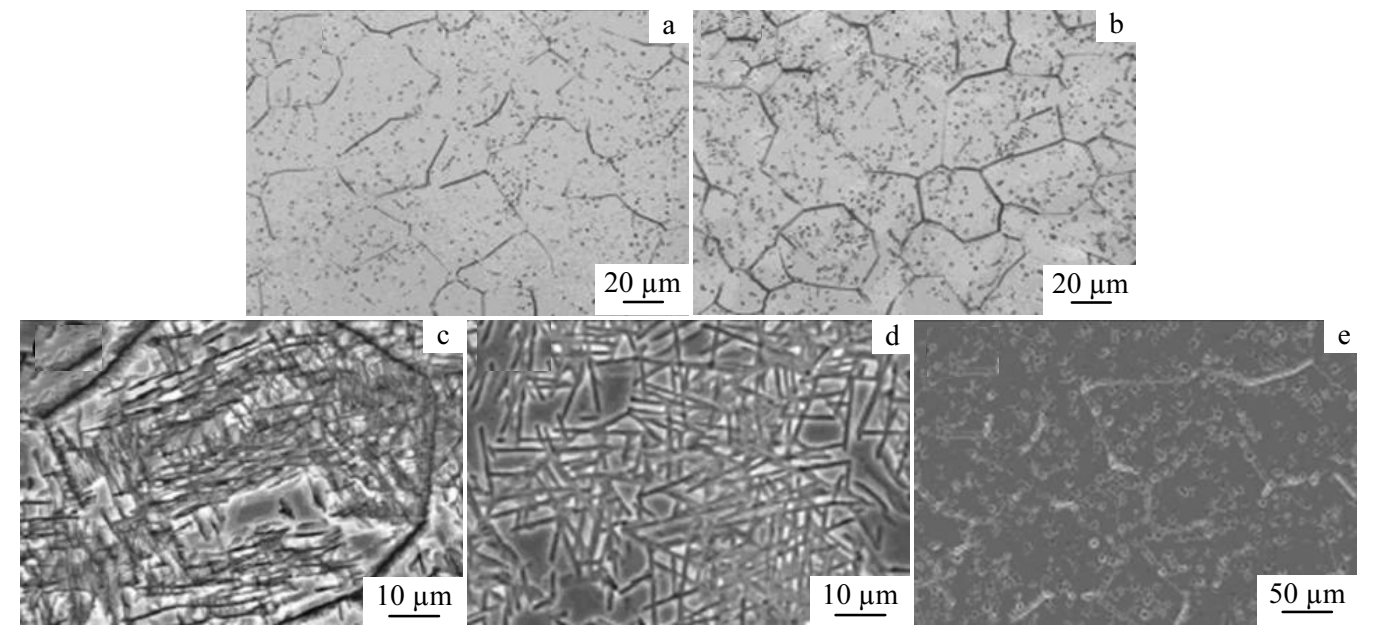

Fig. 3 SEM images of specimens after different solution and aging heat treatments: (a) $300{ }^{\circ} \mathrm{C}, 4 \mathrm{~h} ;$ (b) $350{ }^{\circ} \mathrm{C}, 4 \mathrm{~h} ;\left(\right.$ c) $400{ }^{\circ} \mathrm{C}, 4 \mathrm{~h} ;(\mathrm{d}) 450{ }^{\circ} \mathrm{C}, 4 \mathrm{~h}$; and $(\mathrm{e}) 500{ }^{\circ} \mathrm{C}, 4 \mathrm{~h}$ 

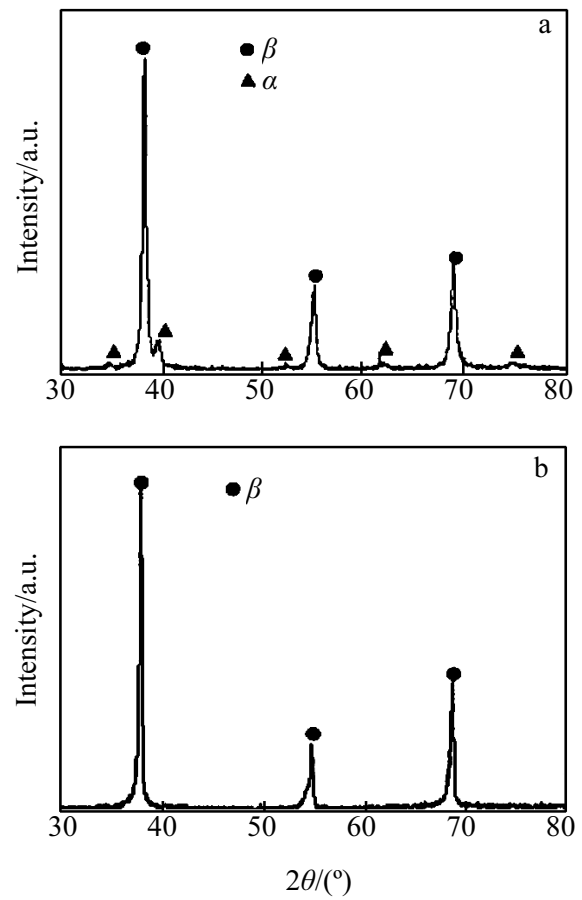

Fig.4 XRD patterns of specimens after different solution and aging heat treatments: (a) $780{ }^{\circ} \mathrm{C}, 1 \mathrm{~h}+400{ }^{\circ} \mathrm{C}, 4 \mathrm{~h}$ and (b) $780{ }^{\circ} \mathrm{C}, 1$ $\mathrm{h}+500^{\circ} \mathrm{C}, 4 \mathrm{~h}$
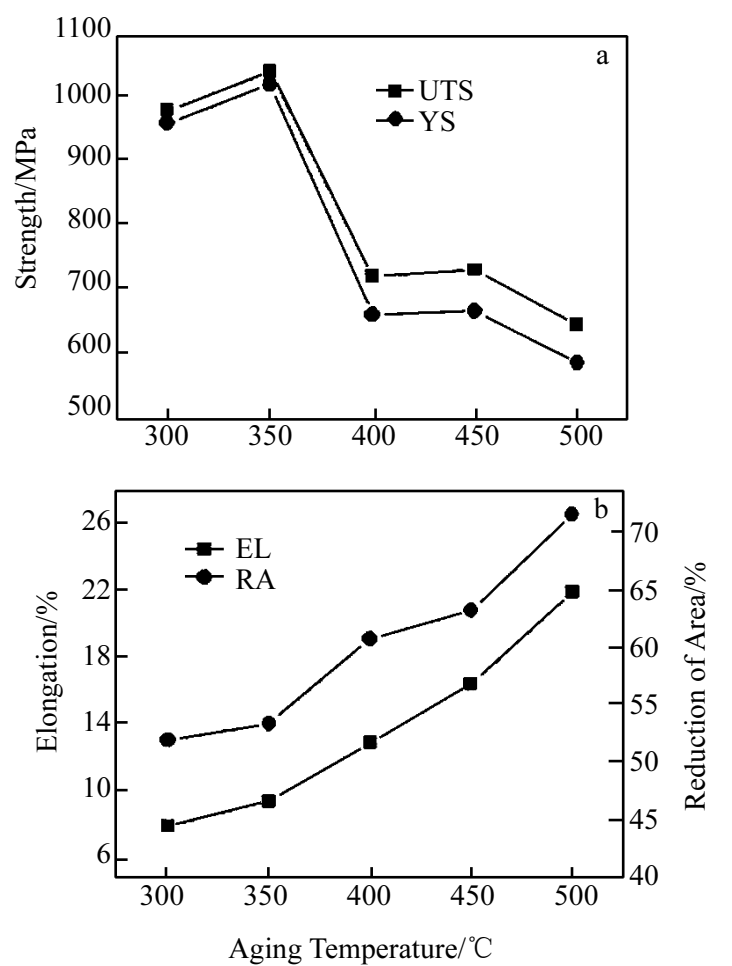

Fig.5 Mechanical properties of alloys after solution and aging heat treatment: (a)strength and (b)plasticity at $300{ }^{\circ} \mathrm{C}$ and $350{ }^{\circ} \mathrm{C}$ changed quickly. The ultimate tensile strength increased up to $980 \mathrm{MPa}$ and $1040 \mathrm{MPa}$, respectively (Fig.5a). While the elongation decreased to $8 \%$ and $9 \%$ rapidly(Fig.5b). When the samples were aged at $400{ }^{\circ} \mathrm{C}$ and $450{ }^{\circ} \mathrm{C}$ with the increase of aging temperature, the ultimate tensile strength kept around $720 \mathrm{MPa}$ and the elongation increased to $13 \%$ and $16 \%$, respectively. Lower ultimate tensile strength (660 $\mathrm{MPa}$ ) and higher elongation(21\%) were obtained when the alloy was aged at $500^{\circ} \mathrm{C}$. As the SEM image and XRD pattern analysis show, no any other phases were observed except single $\beta$ phase under this condition. As former researches ${ }^{[13]}$ studied, when the aging temperature was low(below $400{ }^{\circ} \mathrm{C}$ ), $\omega$ phase with high strength and hardness appeared for most $\beta$ titanium alloys. As for the studied TiNbZr alloy, $\omega$ phase contributed much to the strength of the alloy at $300^{\circ} \mathrm{C}$ and $350^{\circ} \mathrm{C}$. Owing to the little-size and dispersive distribution, it was difficult to observe $\omega$ phase by SEM image and XRD pattern analysis.

\subsection{Microstructure and mechanical properties of the alloy aged for different time}

The micrographs of the alloy aged for different time were shown in Fig.6. According to the OM micrographs (Fig.6a, b, c), much more $\alpha$ phase precipitation along gain boundaries and inside gains occurred when the aging time increased up to $8 \mathrm{~h}$ and $10 \mathrm{~h}$, respectively, compared with that of $4 \mathrm{~h}$. As the SEM images show (Fig.6d, e), a large amount of needle-shaped $\alpha$ phases appeared among $\beta$ phase matrix. It was investigated that the aging time was beneficial to $\alpha$ phase precipitation. When the aging temperature was $400{ }^{\circ} \mathrm{C}$ and $450{ }^{\circ} \mathrm{C}$, the strength of the alloy increased gradually; meanwhile the plasticity decreased. When the aging time was longer than $9 \mathrm{~h}$, the strength of the specimen keptthe same level. The ultimate tensile strength increased to $850 \mathrm{MPa}$ and the elongation kept around $11 \%$ when the alloy was aged at $400{ }^{\circ} \mathrm{C}$ for $9 \mathrm{~h}$. The alloy was strengthened much more quickly at $400{ }^{\circ} \mathrm{C}$ compared with that at $450{ }^{\circ} \mathrm{C}$ shown in Fig.7. As it is known, $\alpha$ phase is a "hard" or "brittle" phase when it is needle-like and dispersive among $\beta$ matrix. It can be conferred that when the aging temperature was $400{ }^{\circ} \mathrm{C}$, needle-like $\alpha$ phase precipitated more quickly with the increase of aging time, which strengthened the alloy more drastically.

\subsection{Characteristic of fracture surface}

Fig. 8 displays SEM images of the fracture surfaces of solid solution treated samples. Many more cleavage planes appeared on the fracture surface of the sample aged at $350{ }^{\circ} \mathrm{C}$ for $4 \mathrm{~h}$. Few whirlpool-like patterns were observed under this condition(Fig.8a). As studied above, friable $\omega$ phase, which contributed much to the increase of strength (over $1000 \mathrm{MPa}$ ) induced clear friable characterization of the fracture surface. The fracture morphologies mainly exhibited toughness fracture in the samples aged at $400{ }^{\circ} \mathrm{C}$ for $4 \mathrm{~h}$ and $9 \mathrm{~h}$, respectively (Fig.8b, c). The alloy tolerated a large amount of elongation before failure occurred. Whirlpool-like patterns were somewhat different due to the aging time. Owing to less $\alpha$ phase 


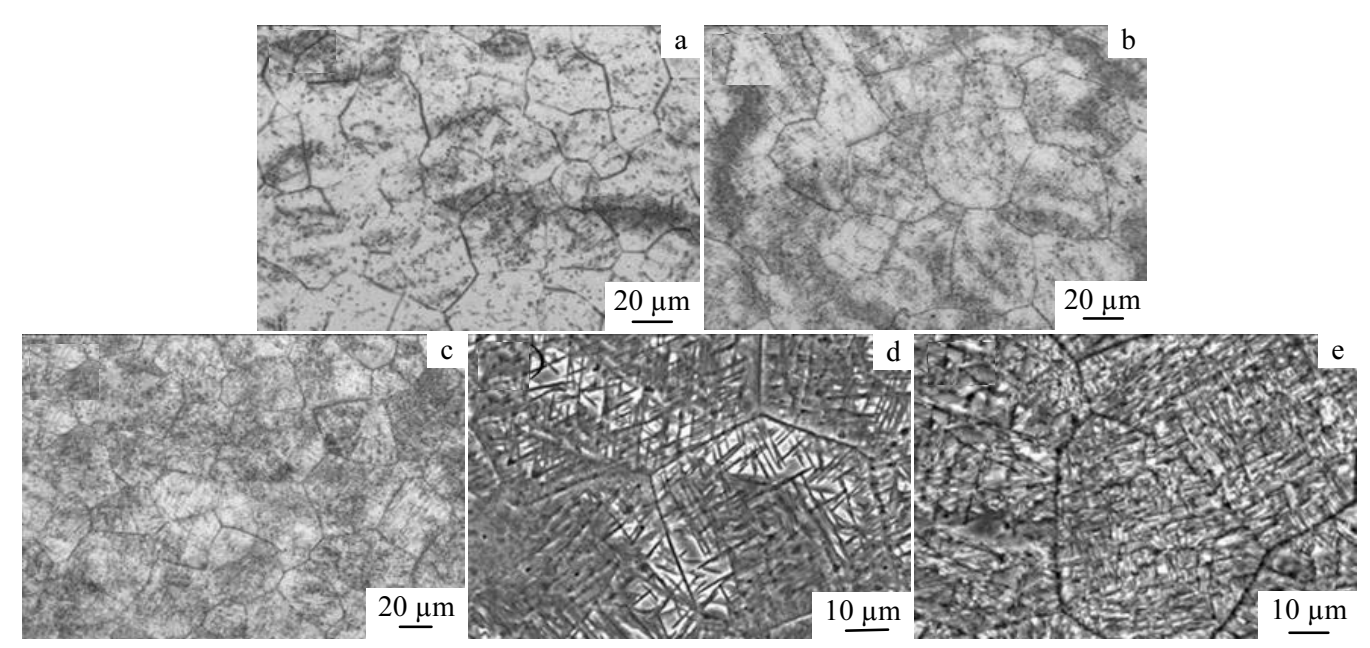

Fig.6 OM(a,b,c) and $\operatorname{SEM}(\mathrm{d}, \mathrm{e})$ micrographs of specimen after solution at $780^{\circ} \mathrm{C}$ for $1 \mathrm{~h}$ and aging at $400{ }^{\circ} \mathrm{C}$ for: (a) $4 \mathrm{~h}$; (b, d) $8 \mathrm{~h}$; and (c, e) $10 \mathrm{~h}$

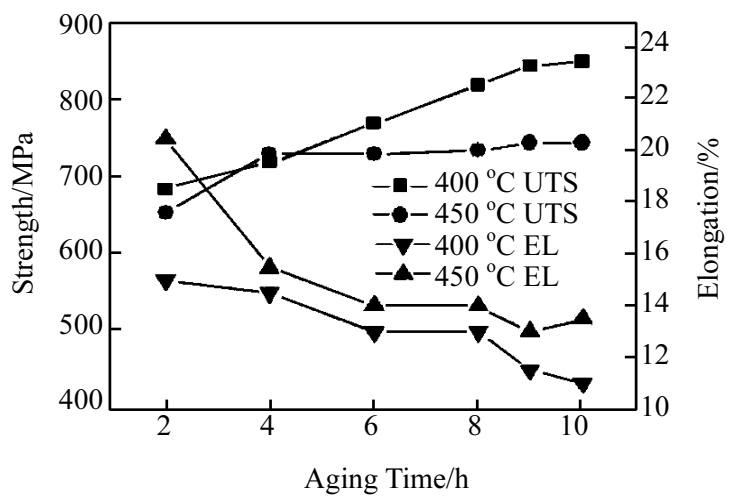

Fig.7 Influence of aging time on mechanical properties of specimens aged at $400{ }^{\circ} \mathrm{C}$ and $450{ }^{\circ} \mathrm{C}$

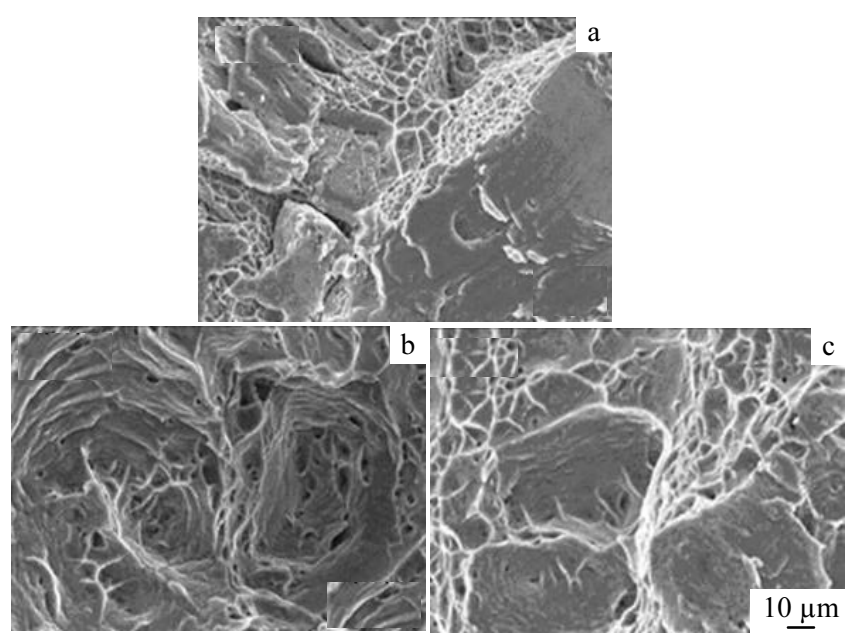

Fig.8 High-magnification SEM images of the fracture surfaces of solid solution treated specimens: (a) $7800^{\circ} \mathrm{C}, 1 \mathrm{~h}+350^{\circ} \mathrm{C}, 4 \mathrm{~h}$; (b) $780{ }^{\circ} \mathrm{C}, 1 \mathrm{~h}+400{ }^{\circ} \mathrm{C}, 4 \mathrm{~h}$; and (c) $780{ }^{\circ} \mathrm{C}, 1 \mathrm{~h}+400{ }^{\circ} \mathrm{C}, 9 \mathrm{~h}$ precipitation in the sample aged for $4 \mathrm{~h}$, fracture morphologies of whirlpool-like patterns were much deeper, seen from high-magnification SEM images in Fig.8b.

\section{Conclusions}

1) No $\alpha^{\prime \prime}$ martensite transformation from $\beta$ occurs when the sample is cooled to room temperature during solid solution.

2) $\alpha$ phase precipitation appears upon the treatment of solution for $1 \mathrm{~h}$, followed by aging at $400{ }^{\circ} \mathrm{C}$ and $450{ }^{\circ} \mathrm{C}$.

3) The aging time plays an important part in $\alpha$ phase precipitation. The ultimate tensile strength increases to $850 \mathrm{MPa}$ and the elongation keeps around $11 \%$ when the alloy is aged at $400{ }^{\circ} \mathrm{C}$ for $9 \mathrm{~h}$.

\section{References}

1 Okazaki Y, Ito Y, Kyo K et al. Mater Sci Eng A[J], 1996, 213: 138

2 Kuroda D, Niinomi M, Morinaga M et al. Mater Sci Eng $A[\mathrm{~J}]$, 1998, 243: 244

3 Banerjee R, Nag S, Stechschulte J. Biomaterials[J], 2004, 25: 3413

4 Takahashi E, Sakurai T, Watanabe S et al. Mater Trans[J], 2002, 43: 2978

5 Kim H Y, Hashimoto S, Kim J I et al. Mater Sci Eng A[J], 2006, 417: 120

6 Yang G J, Zhang T. J Alloys Compd[J], 2005, 92: 291

7 Kim H Y, Sasaki T, Okutsu K. Acta Mater[J], 2006, 54: 423

8 Saito T, Furuta T, Hwang J H et al. Science[J], 2003, 300: 464

9 Ilyin A A, Yu M Kollerov, Golovin I S. J Alloys Compd[J], 1997, 253 254: 144

10 Ferrandini P L, Cardoso F F, Souza S A et al. J Alloys Compd[J], 2007, 433: 207

11 Inamura T, Fukui Y, Hosoda H et al. Mater Trans[J], 2004, 45: 1083

12 Moffat D L, Larbalestier D C. Metall Trans A[J], 1988, 19: 1677

13 Tang X, Ahmed T, Rack H J. J Mater Sci[J], 2000, 35: 1805 


\title{
TiNbZr 合金在热处理过程中的微观组织和力学性能
}

\author{
王立强 ${ }^{1}$, 杨冠军 ${ }^{2}$, 杨华斌 ${ }^{3}$, 曹继敏 ${ }^{3}$, 吕维洁 ${ }^{1}$, 张 荻 ${ }^{1}$ \\ (1. 上海交通大学 金属基复合材料国家重点实验室，上海 200240) \\ (2. 西北有色金属研究院，陕西 西安 710016) \\ (3. 西安赛特金属材料开发有限公司, 陕西 西安 710016)
}

\begin{abstract}
摘 要: TiNbZr 合金由真空自耗电弧炉熔炼。研究了固溶, 时效处理对该合金的微观组织和力学性能的影响。结果显示, 当合金固溶 处理 $1 \mathrm{~h}$ 后在 300 和 $350^{\circ} \mathrm{C}$ 时效处理时，合金的抗拉强度高达 $1000 \mathrm{MPa}$ 。当固溶后的合金在 400 和 $450^{\circ} \mathrm{C}$ 时效处理时 出现 $\alpha$ 相。时 效时间对 $a$ 相的析出有重要的作用。当合金在 $400^{\circ} \mathrm{C}$ 时效处理 $9 \mathrm{~h}$ 后，抗拉强度为 $850 \mathrm{MPa}$, 延伸率也保持在 $11 \%$ 左右。 关键词: $\beta$ 钛合金; 热处理; 显微组织; 力学性能

作者简介: 王立强, 男, 1980 年生, 博士生, 上海交通大学 金属基复合材料国家重点实验室, 上海 200240, 电话: 021-54749117, E-mail: wang_liqiang@163.com
\end{abstract}

